\title{
Investigating waste generated from logging in the Amazon for energy use
}

\author{
Investigando os resíduos gerados da exploração madeireira na Amazônia \\ раra o uso energético
}

\author{
Weslley Wilker Corrêa Morais ${ }^{1}$ (D) , José Otávio Brito² (1), Artur Queiroz Lana² (1), \\ Ananias Francisco Dias Júnior ${ }^{3}$ (D), Janice Bittencourt Facco Morais ${ }^{1}$ (D) \\ ${ }^{1}$ Universidade Estadual de Roraima - UERR, Rorainópolis, RR, Brasil \\ 2Escola Superior de Agricultura “Luiz de Queiroz" - ESALQ, Universidade de São Paulo - USP, Piracicaba, SP, Brasil \\ ${ }^{3}$ Universidade Federal do Espírito Santo - UFES, Jerônimo Monteiro, ES, Brasil
}

\begin{abstract}
How to cite: Morais, W. W. C., Brito, J. O., Lana, A. Q., Dias Júnior, A. F., \& Morais, J. B. F. (2021). Investigating waste generated from logging in the Amazon for energy use. Scientia Forestalis, 49(132), e3712.

https://doi.org/10.18671/scifor.v49n132.15
\end{abstract}

\begin{abstract}
Wood residues can go to waste due to a lack of knowledge of their properties. In order to contribute to the use of materials, the objective was to individually assess the physical and chemical characteristics of Amazonian wood waste. Due to the lack of information about most Amazonian tree species, Eucalyptus grandis was defined as a control treatment. The following tests carried out were: granule size, moisture, wood basic density, residuals bulk density, pH, total extractives, lignin, holocellulose, volatile matter, ash, fixed carbon, high and lower heating values and liquid energy density. The evaluated species presented different characteristics for the physical, chemical, and energetic tests of wood residues. In general, the Amazonian species showed superior characteristics in comparison to Eucalyptus grandis for energy production. Qualea paraenses, Cedrela sp., Dinizia excelsa, Ocotea cinerea and Buchenavia grandis need to be further investigated for energy purpose due to the low pH. Based on the data obtained, it would be recommended to adopt pre-treatments as a way to increase the energy performance of biomass.
\end{abstract}

Keywords: Wood residues destination; Timber waste; Amazonian species; Sawmills.

\section{Resumo}

Os resíduos madeireiros podem se tornar rejeitos, devido ao desconhecimento de suas características. Como forma de contribuir para a utilização destes materiais, objetivou-se avaliar individualmente as características físicas e químicas dos resíduos amazônicos. Devido à ausência de informações de grande parte das espécies amazônicas foi definido o Eucalyptus grandis como tratamento controle. Os ensaios realizados foram: granulometria, umidade base úmida, densidade básica da madeira, densidade à granel, $\mathrm{pH}$, extrativos totais, lignina, holocelulose, materiais voláteis, cinza, carbono fixo, poder calorífico superior e útil e densidade energética líquida. As espécies avaliadas apresentaram características distintas para os ensaios físicos, químicos e energéticos dos resíduos madeireiros. De maneira geral, as espécies amazônicas apresentaram características superiores em relação ao Eucalyptus grandis para produção energética. As espécies Qualea paraenses, Cedrela sp., Dinizia excelsa, Ocotea cinerea e Buchenavia grandis, devem ser melhor estudadas para a produção energética, devido ao baixo pH. Com base nos dados obtidos, se recomenda a adoção de pré-tratamento, como forma de elevar o desempenho energético da biomassa.

Palavras-chave: Destinação de resíduos madeireiros; Resíduos de madeira; Espécies amazônicas; Serrarias.

Financial support: None.

Conflict of interest: Nothing to declare.

Corresponding author: weslley_eng@yahoo.com.br

Received: 9 May 2021

Accepted: 30 September 2021.

Editor: Mauro Valdir Schumacher.

(c) This is an Open Access article distributed under the terms of the Creative Commons Attribution License, which permits unrestricted use,

c) distribution, and reproduction in any medium, provided the original work is properly cited. 


\section{INTRODUCTION}

The Brazilian Amazon region is known as one of the main production areas for tropical native wood worldwide (Melo et al., 2019). However, the efficiency and use of sawmill logs located in the Brazilian Amazon are considered low, mainly due to the use of outdated technologies, inadequate machinery operating conditions, and low labor qualification, which are factors that contribute to the greater generation of wood waste (Paixão et al., 2014). There are also factors inherent to the forest, for example: the use of a varied number of log and species diameters, without any adaptation in the sawing process, the ease of obtaining the raw material and the presence of defects in the logs (Melo et al., 2019; Ramos et al., 2018). Therefore, it is essential to ask how science can contribute to the best possible use of wood waste.

Despite all the productive potential, the wood producing areas of the Amazon region face difficulties in determining the proper end use and valorization of the residues generated during the log breakdown and sawing process (Soares et al., 2018). According to the DOF (document of forest origin) report by IBAMA (Brazilian Institute of Environment and Natural Resources) in 2017, approximately $92000 \mathrm{~m}^{3}$ of wood residues were produced in Roraima (Instituto Brasileiro do Meio Ambiente e dos Recursos Naturais Renováveis, 2021). Due to the lack of viable alternatives for Amazon region waste, the environmental licensing processes of sawmills have become time consuming, which contributes to their illegal exploitation (Crivelli et al., 2017). In addition, the energy issue in the Amazon region is the greatest challenge for industrial development (Coelho et al., 2010). In this context, the high availability of wood waste combined with its use for energy production can mitigate the recurrent energy problems in the Amazon regions that produce lumber.

The lack of information on possible uses and the intrinsic difficulties in the utilization of wood residues in the Amazon result in improper storage or open burning. Therefore, Law $\mathrm{N}^{\circ}$. 12305 was created on August 2, 2010, known as the National Solid Waste Policy (Brasil, 2010), and Normative Instruction $N^{\circ}$. 002/2016 of the State Foundation for the Environment and Water Resources (FEMARH) (Boa Vista, 2016). These prohibit the inadequate storage and burning of wood residues in the open, "even if this practice is part of the environmental studies that guided environmental licensing". In this sense, wood residues have become hurdles for businessmen in the wood sector, due to licensing restrictions, notices, and fines from environmental agencies.

Thus, there is a context of legal obligations for the use of wood waste and, consequently, an abundance of opportunities for studies for the characterization of the material. The objective was to conduct studies of wood waste characterization from Amazonian species with the prospect of energy generation as a first and important technical step to be taken in relation to the theme.

\section{MATERIAL AND METHODS}

Waste collections were carried out during primary and secondary log splitting (diameter $>50 \mathrm{~cm}$ and length of $6 \mathrm{~m}$ ) at sawmills at the Rorainópolis wood pole, Roraima, Brazil, located at $0^{\circ} 56^{\prime} 44^{\prime \prime} \mathrm{N}$ and $60^{\circ} 25^{\prime} 6^{\prime \prime} \mathrm{W}$. The residues were collected from eight different sawmills that used similar types of machinery. All sawmills were made up of a single band saw for the primary split and multiple and simple circular saws (cutters) for the secondary split in order to establish the width and length of the boards, respectively.

The wood residue collection for each species was carried out using three different tree logs. Throughout the log sawing process, the residues were collected separately by log and species (Table 1) in polypropylene bags directly from the conveyors, that is, without contact with the ground. The set made up of wood shavings, sawdust, and dust in this study is called the Fine Residues of Log Breakdown by Sawing Processes (FRLBS). 
Table 1. Amazonian species with their respective vernacular names and collection locations.

\begin{tabular}{lcc}
\hline \multicolumn{1}{c}{ Species } & Vernacular names & Collection locations \\
\hline Manilkara huberi (Ducke) A. Chev & maçaranduba & Sawmill 1 \\
Bagassa guianensis Aubl. & tatajuba & Sawmill 1 \\
Andira inermis (W.Wright) DC. & andira & Sawmill 1 \\
Cedrela sp. & cedro - doce & Sawmill 2 \\
Caryocar villosum (Abul.) Pers. & pequiá & Sawmill 2 \\
Hymenaea sp. & jatobá & Sawmill 2 \\
Handroanthus sp. & ipê amarelo & Sawmill 2 \\
Cariniana micrantha Ducke & cachimbeiro & Sawmill 3 \\
Ocotea cinerea van der Werff & louro preto & Sawmill 3 \\
Buchenavia grandis Ducke & tanibuca & Sawmill 4 \\
Qualea paraensis Ducke & rabo de arraia & Sawmill 4 \\
Dinizia excelsa Ducke & angelim - ferro & Sawmill 5 \\
Vatairea guianensis Aubl. & amargoso & Sawmill 6 \\
Iryanthera sp. & ucuúba & Sawmill 7 \\
Hymenolobium excelsum Ducke & angelim - pedra & Sawmill 8
\end{tabular}

Three logs were sampled by species, homogenized individually using a concrete mixer, of which three samples of 200 grams were stored separately, taken prior to drying for the first analysis of the wood. The rest of the FRLBS was dried in an oven at a temperature of $103 \pm 3^{\circ} \mathrm{C}$ until constant weight. The purpose was to reduce the risk of microbial contamination, and this was an essential condition for the transport of the material to the University of São Paulo, Piracicaba, SP, Brazil, where the analyses were carried out. In addition to this material, 20 samples were collected at the sawmills; 10 in the radial direction and 10 longitudinally from the split logs, in order to estimate the wood basic density.

Eucalyptus grandis Hill ex Maiden was used as a reference sample and comparative standard, due to the vast studies and thorough research conducted across the world. The Eucalyptus grandis wood came from commercial plantations of three trees, aged seven years, located in the municipality of Barra do Chápeu, SP, at coordinates $24^{\circ} 30^{\prime} 57.2^{\prime \prime} \mathrm{S}$ and $48^{\circ} 59^{\prime} 59.2^{\prime \prime} \mathrm{W}$.

The granule size analysis of the FRLBS was performed by the screening method, according to the standard NBR 7217 (Associação Brasileira de Normas Técnicas, 1987), using different mesh sieves, $4 \mathrm{~mm}, 0.600 \mathrm{~mm}, 0.425 \mathrm{~mm}, 0.250 \mathrm{~mm}$, and $<0.250 \mathrm{~mm}$ (base), respectively. The determination of the wet base moisture of the FRLBS was performed using the gravimetric method NBR 7190 (Associação Brasileira de Normas Técnicas, 1997).

The determination of the wood basic density was performed by the hydrostatic balance method, according to the standard NBR 11941 (Associação Brasileira de Normas Técnicas, 2003). For classification of basic wood densities by species, the mean from the pieces of logs was considered, applying the following scale (Instituto Brasileiro do Meio Ambiente e dos Recursos Naturais Renováveis, 2021): low $\left(0.310 \mathrm{~g} . \mathrm{cm}^{-3}\right.$ to $\left.0.500 \mathrm{~g} . \mathrm{cm}^{-3}\right)$, medium $\left(0.501 \mathrm{~g} . \mathrm{cm}^{-3}\right.$ to $0.720 \mathrm{~g} . \mathrm{cm}^{-3}$ ), and high (above $0.721 \mathrm{~g} . \mathrm{cm}^{-3}$ ). For the determination of wood residue bulk densities, a $100 \mathrm{~mL}$ beaker was slowly filled with FRLBS at equilibrium moisture up to the edge of the beaker, and then a scale was used to remove excess. The use of the beaker was an adaptation of the standard NBR 6922 (Associação Brasileira de Normas Técnicas, 1981).

To determine the wood $\mathrm{pH}$, the equivalent of 1 gram of absolutely dry FRLBS was placed in a $200 \mathrm{~mL}$ Erlenmeyer filled with $100 \mathrm{~mL}$ of distilled water. The mixture was heated in a water bath at $100^{\circ} \mathrm{C}$ for 60 minutes. After natural cooling, the $\mathrm{pH}$ meter was read, and the result was classified as: strongly acidic ( 0.00 to 3.50 ); weakly acidic (3.51 to 6.50$)$; neutral (6.51 to 7.50 ), weakly alkaline (7.51 to 10.50) and strongly alkaline (10.51 to 14.00), according to the international $\mathrm{pH}$ scale. 
The procedures used to quantify the total extractives and lignin were TAPPI T $204 \mathrm{~cm}-97$ and TAPPI 222 os-74, respectively; and holocellulose was calculated by the total sum of the percentages of lignin and total extractives from 100\% (Technical Association of the Pulp and Paper Industry, 2006, 2007). The immediate chemical analysis of waste in natura was carried out according to the standard NBR 8112 (Associação Brasileira de Normas Técnicas, 1984a).

The high heating value (HHV) was determined in a calorimeter (PARR 1201, Parr Instrument Company, Moline, IL, USA), according to the standard NBR 8633 (Associação Brasileira de Normas Técnicas, 1984b). The lower heating value (LHV) of the wood was calculated according to equation 1 (Ferreira et al., 2014). The net energy density was calculated by multiplying the bulk density and lower heating value.

$$
L H V=(H H V-324)-(1-(\% \text { moisture } * 0.01)) \times(6 \times \% \text { moisture })
$$

(Equation 1)

Where: LHV= lower heating value, also known as net calorific value $\left(\mathrm{MJ}^{\mathrm{k}} \mathrm{kg}^{-1}\right) . \mathrm{HHV}=\mathrm{high}$ heating value (MJ. $\left.\mathrm{kg}^{-1}\right)$.

The data obtained were processed and analyzed using a database constructed in the program Excel®. A completely randomized design of sixteen species was used (15 Amazonian species + Eucalyptus grandis), constituting the dependent variables, and triplicates for each investigated variable. It is noteworthy that the averages presented in the last row of each Table 2 and 3 do not consider the values obtained from Eucalyptus grandis.

\section{RESULTS AND DISCUSSION}

The granule analysis (Table 2) presented low percentage of granules in the upper fraction (> $4.000 \mathrm{~mm}$ ), and this result can be attributed to the absence of sawmill processing units. In other words, the processing units are attained by wood machining, a process subsequent to the splitting. This is carried out by planers and thickening machines, which produce residues larger than $2.5 \mathrm{~mm}$, called shavings, and consequently, these result in an increase in the percentage of granules in the higher fractions.

Table 2. Average particle size distribution of wood waste produced by sawmills in the Amazon Area.

\begin{tabular}{|c|c|c|c|c|c|}
\hline \multirow[b]{2}{*}{ SPECIES } & \multicolumn{5}{|c|}{ percentage retained on the sieve } \\
\hline & $\begin{array}{c}>4.000 \\
\mathrm{~mm}\end{array}$ & $\begin{array}{c}4.000 \mathrm{~mm} \\
- \\
0.600 \mathrm{~mm}\end{array}$ & $\begin{array}{c}0.600 \mathrm{~mm} \\
- \\
0.425 \mathrm{~mm}\end{array}$ & $\begin{array}{c}0.425 \mathrm{~mm} \\
- \\
0.250 \mathrm{~mm}\end{array}$ & $<0.250 \mathrm{~mm}$ \\
\hline Manilkara huberi & $1.7(1.7)$ & $17.5(4.7)$ & $29.6(8.1)$ & $29.6(6.5)$ & $21.6(5.5)$ \\
\hline Bagassa guianensis & $0.1(0.1)$ & $44.3(2.6)$ & $25.9(0.9)$ & $18.9(0.3)$ & $10.7(3.1)$ \\
\hline Andira inermis & $0.6(0.1)$ & $48.6(6.4)$ & $30.0(2.8)$ & $16.3(1.9)$ & $5.0(2.3)$ \\
\hline Cedrela sp. & $0.3(0.2)$ & $69.1(6.6)$ & $16.2(3.3)$ & $8.9(2.3)$ & $5.5(1.0)$ \\
\hline Caryocar villosum & $0.1(0.1)$ & $50.7(10.8)$ & $23.5(4.9)$ & $15.7(5.0)$ & $9.9(1.0)$ \\
\hline Hymenaea sp. & $1.3(0.7)$ & $43.6(11.1)$ & $19.8(4.8)$ & $15.0(5.2)$ & $20.3(0.5)$ \\
\hline Handroanthus sp. & $1.5(1.6)$ & $25.4(9.7)$ & $27.9(2.6)$ & $24.9(8.1)$ & $20.4(3.4)$ \\
\hline Cariniana micrantha & $1.0(0.4)$ & $54.4(3.4)$ & $16.5(1.5)$ & $17.6(1.7)$ & $10.4(2.7)$ \\
\hline Ocotea cinerea & $0.5(0.4)$ & $62.7(8.7)$ & $18.0(3.9)$ & $10.9(3.5)$ & $7.8(1.1)$ \\
\hline Buchenavia grandis & $1.7(0.1)$ & $39.7(7.0)$ & $23.1(0.8)$ & $20.2(3.7)$ & $15.3(2.8)$ \\
\hline Qualea paraensis & $0.3(0.1)$ & $43.8(24.6)$ & $31.9(12.6)$ & $13.3(9.4)$ & $10.7(3.4)$ \\
\hline Dinizia excelsa & $0.2(0.1)$ & $26.1(4.7)$ & $25.5(0.1)$ & $26.4(2.7)$ & $21.8(2.1)$ \\
\hline Vatairea guianensis & $2.1(0.2)$ & $66.0(1.0)$ & $21.4(1.5)$ & $8.4(0.4)$ & $2.1(0.1)$ \\
\hline Iryanthera sp. & $0.4(0.2)$ & $78.6(11.2)$ & $14.1(7.0)$ & $5.2(2.7)$ & $1.7(1.4)$ \\
\hline Hymenolobium excelsum & $0.3(0.2)$ & $21.0(2.6)$ & $39.1(2.6)$ & $33.1(2.8)$ & $6.4(2.1)$ \\
\hline $\bar{X}$ & 0.8 & 46.1 & 24.2 & 17.6 & 11.3 \\
\hline
\end{tabular}

$\bar{X}$ : General average of tests for Amazonian species. 
The largest amounts of dust were produced by Dinizia excelsa, Manilkara huberi e Handroanthus sp., $21.8 \%, 21.6 \%$ and $20.4 \%$ respectively. Compared to softer woods, it is known that species considered hard, of high density, have greater resistance to penetration to the saw teeth, and consequently, produce a greater proportion of dust lower than $0.250 \mathrm{~mm}$ (Cassilha et al., 2004), when compared to softwoods. Dinizia excelsa, Manilkara huberi and Handroanthus sp. offered resistance to penetration of 14,318 N (Instituto de Pesquisas Tecnológicas, 2017a) and 9,611 N (Instituto de Pesquisas Tecnológicas, 2017b) e 10,807 N (Instituto de Pesquisas Tecnológicas, 2017c), respectively, and they are classified as hardwoods (> 8,006 N), according to the classification suggested by Tom \& Peter Flooring Inc (2021). Vatairea guianensis presented a value of 6,816 N (Instituto de Pesquisas Tecnológicas, 2017d), had a medium hardness wood (5,338 $\mathrm{N}$ to 8,006 N), and the highest concentration of granules in the upper fractions. According to the wood residues classification suggested by Cassilha et al. (2004), the predominance of fractions less than $4.000 \mathrm{~mm}$ up to $0.600 \mathrm{~mm}$ and less than $0.600 \mathrm{~mm}$ up to $0.425 \mathrm{~mm}$ is noted. These comprised approximately $70 \%$ of the total value, and they mostly represent sawdust $(2.500 \mathrm{~mm}$ to $0.500 \mathrm{~mm})$. It is worth mentioning that the granule size of the residues affects the conversion rate during the burning. In smaller fractions, there is a reduction of empty spaces for oxygen penetration, due to the compaction in the combustion chamber, which reduces the energy conversion efficiency, but the reverse occurs for the larger fractions (Haberle et al., 2018).

The lowest moisture contents (Table 3) were below 30\%, obtained from Handroanthus sp., Manilkara huberi and Cariniana micranta. The reason for the lower moisture observed for the Handroanthus sp. and Manilkara huberi species is related to the log storage time in the yard. Normally, species with high economic value are sold in large lots, requiring the storage of the logs. In addition, it is noted that the collections were carried out in November, a month of low rainfall in the municipality of Rorainópolis.

Table 3. Moisture content on wet weight base e $\mathrm{pH}$ and rating of residues of Amazonian species and Eucalyptus grandis.

\begin{tabular}{lccc}
\hline \multicolumn{1}{c}{ SPECIES } & MCW (\%) & pH & pH rating \\
\hline Manilkara huberi & $28.31(3.93)$ & $5.26(0.07)$ & Weakly acid \\
Bagassa guianensis & $38.16(5.54)$ & $6.45(0.23)$ & Weakly acid \\
Andira inermis & $49.12(1.01)$ & $6.74(0.04)$ & Neutral \\
Cedrela sp. & $34.98(0.83)$ & $4.71(0.13)$ & Weakly acid \\
Caryocar villosum & $43.75(1.45)$ & $6.15(0.06)$ & Weakly acid \\
Hymenaea sp. & $34.07(2.70)$ & $5.37(0.13)$ & Weakly acid \\
Handroanthus sp. & $18.90(2.39)$ & $5.47(0.19)$ & Weakly acid \\
Cariniana micrantha & $29.97(2.82)$ & $5.67(0.09)$ & Weakly acid \\
Ocotea cinerea & $50.05(1.04)$ & $4.48(0.13)$ & Weakly acid \\
Buchenavia grandis & $32.15(2.53)$ & $4.31(0.06)$ & Weakly acid \\
Qualea paraensis & $39.20(2.54)$ & $4.72(0.18)$ & Weakly acid \\
Dinizia excelsa & $32.15(6.48)$ & $4.66(0.06)$ & Weakly acid \\
Vatairea guianensis & $44.38(5.47)$ & $5.08(0.03)$ & Weakly acid \\
Iryanthera sp. & $49.51(3.23)$ & $5.73(0.09)$ & Weakly acid \\
Hymenolobium excelsum & $48.18(0.58)$ & $6.77(0.04)$ & Neutral \\
Eucalyptus grandis & $34.93(0.72)$ & $5.28(0.02)$ & Weakly acid \\
\multicolumn{1}{c}{$\bar{X}$} & 38.19 & 5.44 & \\
\hline
\end{tabular}

$\bar{X}$ : General average of tests for Amazonian species. MCW: Moisture content on wet weight base. $\mathrm{pH}$ : Hydrogen potential. 
As for energy, it can be observed that all species should be subjected to drying in order to increase the energy conversion efficiency of waste. This can be achieved through solar drying with a cover (rainy season in the region) or by longer storage of residues in the dry season. Moisture content causes a reduction in energy conversion, due to the loss of energy to evaporate the water contained in the wood. In addition, it is known that high moisture content values reduce both the temperature of the gases generated and the pressure at the combustion chamber exit, which consequently favors the formation of soot crusts inside the combustion chamber and in the chimneys (Dzurenda \& Banski, 2017). These problems can impair the equipment performance during biomass combustion for energy purposes.

In Table 3, the pH ranged from 4.31 (Buchenavia grandis) to 6.77 (Hymenolobium excelsum), considered to be of low acidity and neutral, respectively. The species considered neutral were Hymenolobium excelsum (6.77) and Andira inermis (6.74), and the other species were considered of low acidity, including Eucalyptus grandis. Iwakiri et al. (2015) claimed that the wood pH is between 3.00 and 5.50; however, values above the reported range were observed. The difference between the intervals obtained and the literature can be explained by the lack of standardization and, consequently, the adoption of different methods.

Measuring the $\mathrm{pH}$ and the amount of contaminants present in the biomass are important for energy production, due to their influence on boiler corrosion processes (Cotton, 2000). During operation, the boiler tubes form protective layers to resist corrosion, consisting mainly of magnetite (Namduri \& Nasrazadani, 2008). However, magnetite at $310^{\circ} \mathrm{C}$ becomes unstable and soluble at pH below 5 and above 12, making the tubes vulnerable to corrosion (American Society for Metals, 1990). According to Table 3, Qualea paraenses, Cedrela sp., Dinizia excelsa, Ocotea cinerea and Buchenavia grandis species have lower $\mathrm{pH}$ than recommended, however it is worth analyzing the $\mathrm{pH}$ of the gases generated by the combustion of these species residues.

The highest averages for wood basic density were observed in the Dinizia excelsa

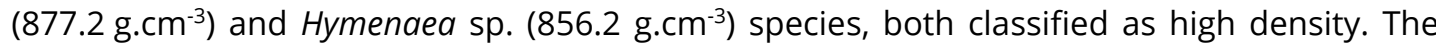
lowest basic densities were measured for Cedrela sp. $\left(407.3{\mathrm{~g} . \mathrm{cm}^{-3}}^{-3}\right)$ and Eucalyptus grandis $\left(452.6{\mathrm{~g} . \mathrm{cm}^{-3}}^{-}\right.$), classified as being of low density (Figure 1). In the literature, the wood basic density for Dinizia excelsa, Hymenaea sp. and Cedrela sp. varied between $830.0{\mathrm{~g} . \mathrm{cm}^{-3}}^{-3}$ to $880.0 \mathrm{~g} . \mathrm{cm}^{-3}$ and $380.0 \mathrm{~g} . \mathrm{cm}^{-3}$ to $431.0 \mathrm{~g} . \mathrm{cm}^{-3}$, respectively (Nascimento et al., 2016; Quirino et al., 2004; Araújo 2007; Valério et al., 2009). It is observed that the mentioned intervals include the values observed in this study.

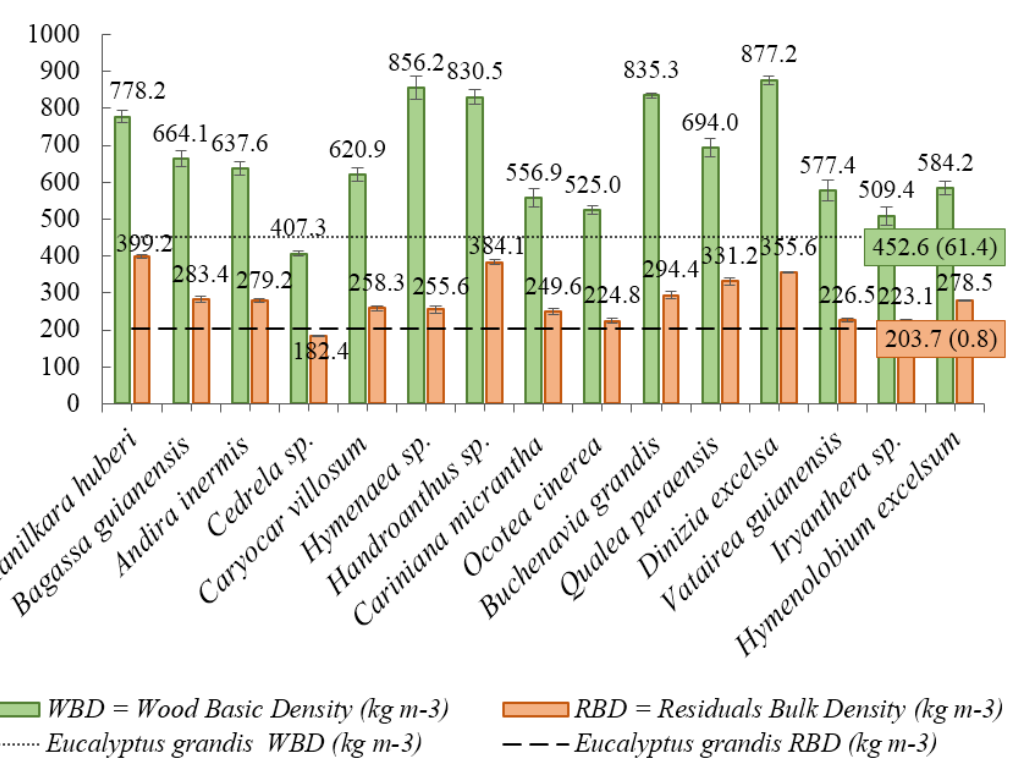

Figure 1. Average values obtained for wood basic density and bulk density of wood waste produced by sawmills in the Amazon Area and Eucalyptus grandis. 
The species with the highest residue bulk density (RBD) was Manilkara huberi and the lowest were observed for Cedrela sp. and Eucalyptus grandis, which varied from $399.2 \mathrm{~kg} \cdot \mathrm{m}^{-3}$ to $182.4 \mathrm{~kg} \cdot \mathrm{m}^{-3}$ (Figure 1). The residuals' bulk density (RBD) results differ from those obtained by Pinheiro et al. (2005) at $150.00 \mathrm{~kg} \cdot \mathrm{m}^{-3}$ (Vochysia sp.) and $200.00 \mathrm{~kg} \cdot \mathrm{m}^{-3}$ (Couratari sp.), that were both obtained at $12 \%$ humidity. It is noted that different species, moisture, wood density, and granule size may have influenced RBD.

Bulk density represents the amount of material considering as empty space. At constant volume, this characteristic is strongly associated with the granule size of the waste. It is important to note that the higher the bulk density results in greater the amount of material for energy conversion. However, according to Obernberger and Thek (2004), low bulk density values result in increased transportation and storage costs.

Based on Figure 2, it can be seen that only Qualea paraensis (4.5\%) and Cariniana micranta (4.7\%) had a total extractive content of less than $5 \%$. The species that presented the highest extractive content was Vatairea guianensis (21.7\%), approximately seventeen times higher than Eucalyptus grandis (1.3\%). In the literature, the values of total extractives of Amazonian species vary from $0.6 \%$ to $20.1 \%$ for Pouteria pachycarpa (abiurana) and Dipteryx odorata (cumaru), respectively (Santana \& Okino, 2007; Zau et al., 2014), and this interval contains all the species studied with the exception of Vatairea guianensis. Despite the high value obtained by Vatairea guianensis, Bowyer et al. (2003) explain that the total extraction of wood can reach $30 \%$ of the wood dry weight.

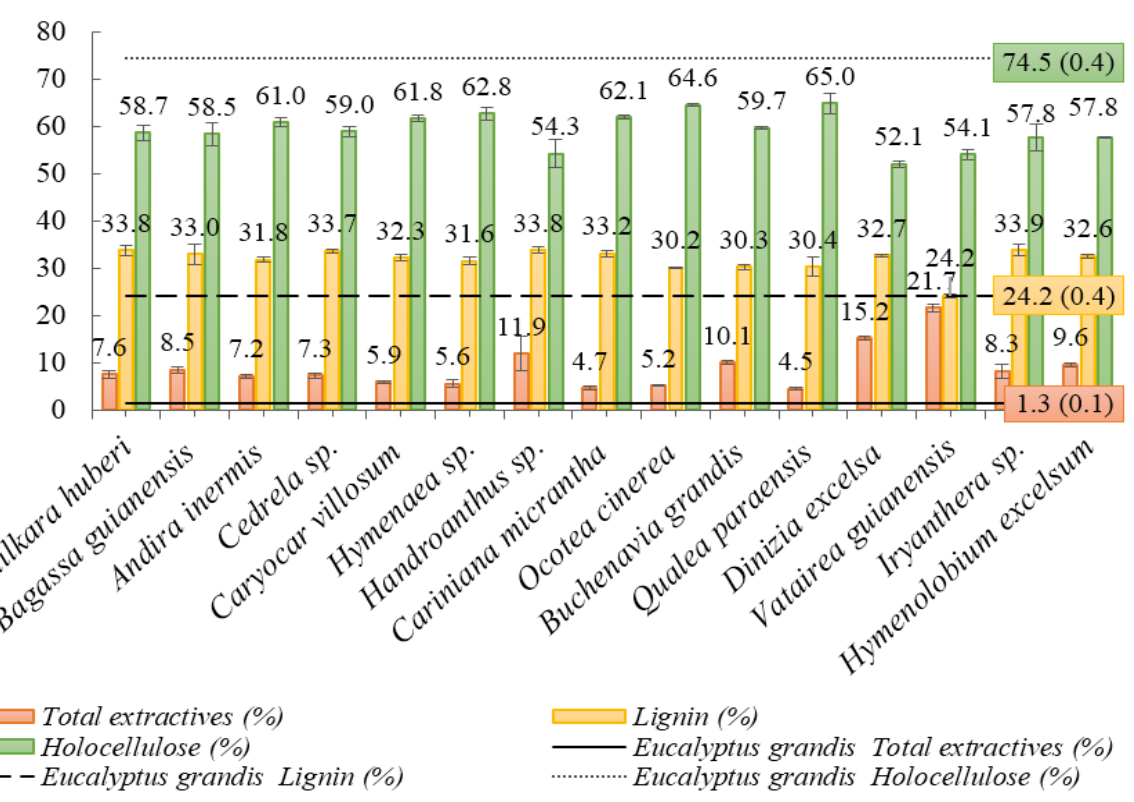

Figure 2. Average values obtained for total extractives, lignin and holocellulose of wood residues produced by sawmills in the Amazon Area and Eucalyptus grandis.

For energy use, high percentages of extractives present in the wood can contribute to the corrosion of the equipment used in the energy conversion of biomass (Sarto \& Sansigolo, 2010), mainly due to the acidic nature of some woods (Table 3). As a result, there may be an increased need for maintenance and replacement of parts, resulting in an increase in the energy production costs. The higher presence of volatile matters also implies in a nonconstant supply of combustion chambers, since they are more easily released during thermal degradation.

It can be seen in Figure 2 that the percentages of lignin for Amazonian species ranged from $24.2 \%$ (Vatairea guianensis) to $33.9 \%$ (Handroanthus sp.). In the literature, the lignin values of Amazonian species vary from $26.0 \%$ to $34.3 \%$ for breu-branco (Dacryodes sp.) and cumaru (Dipteryx odorata), respectively (Santana \& Okino, 2007; Zau et al., 2014), and this interval 
encompasses all species studied in this work, except for Vatairea guianensis. According to Klock et al. (2006) and Castro et al. (2015), lignin can vary from 20\% to 35\% of the wood's dry weight, and this interval includes all presently evaluated species.

Species with high lignin values above $30 \%$ usually result in a longer burning time in the combustion chamber, facilitating control and, consequently, increasing the process performance (Brand, 2010; Dorez et al., 2014). This can be attributed to the higher thermal resistance of lignin when compared to holocellulose, and this is caused by the difference in the percentage of fixed carbon, $65 \%$ and $45 \%$, respectively (Pereira et al., 2000). Therefore, the other Amazonian species have lignin levels above 30\% with the exception of Vatairea guianensis.

The highest holocellulose values among the Amazonian species were observed for Qualea paraensis (65.0\%) and Ocotea cinerea (64.6\%), respectively. However, Qualea paraenses and Ocotea cinerea showed lower values than Eucalyptus grandis (Figure 2). In the literature, the holocellulose values of Amazonian species vary from 58.3\% to $72.3 \%$ for cumaru (Dipteryx Odorata) and breu-branco (Dacryodes sp.), respectively (Santana \& Okino, 2007; Zau et al., 2014), and this interval represents all presently studied species except for Vatairea guianensis. This behavior from Vatairea guianensis was expected, mainly due to the values obtained for extractives and lignin. As for energy use, according to Santos et al. (2013), cellulose and hemicellulose have lower calorific values when compared to lignin; however, holocellulose is important mainly due to its higher percentage in wood.

The highest values obtained for volatile matter (VM) were obtained in Caryocar villosum and Eucalyptus grandis (Figure 3). The MV values of Amazonian species ranged from $76.6 \%$ to $84.0 \%$, and in the literature, values between $78.1 \%$ (Dinizia excelsa) and 83.0\% (Caryocar villosum), respectively, were found for Hymenolobium petraeum (Cruz et al., 2016) and Dalbergia sp. (Dias et al., 2019), which are both Amazonian species. Note that only Dinizia excelsa does not belong to the range mentioned above. It is known that volatile matter when burned is mainly composed of gases (hydrogen, $\mathrm{CO}$ e $\mathrm{CO}_{2}$ ) and hydrocarbons, among others, and these result from the plant physiological reactions in response to edaphic-climatic conditions, which can explain the behavior of Dinizia excelsa.

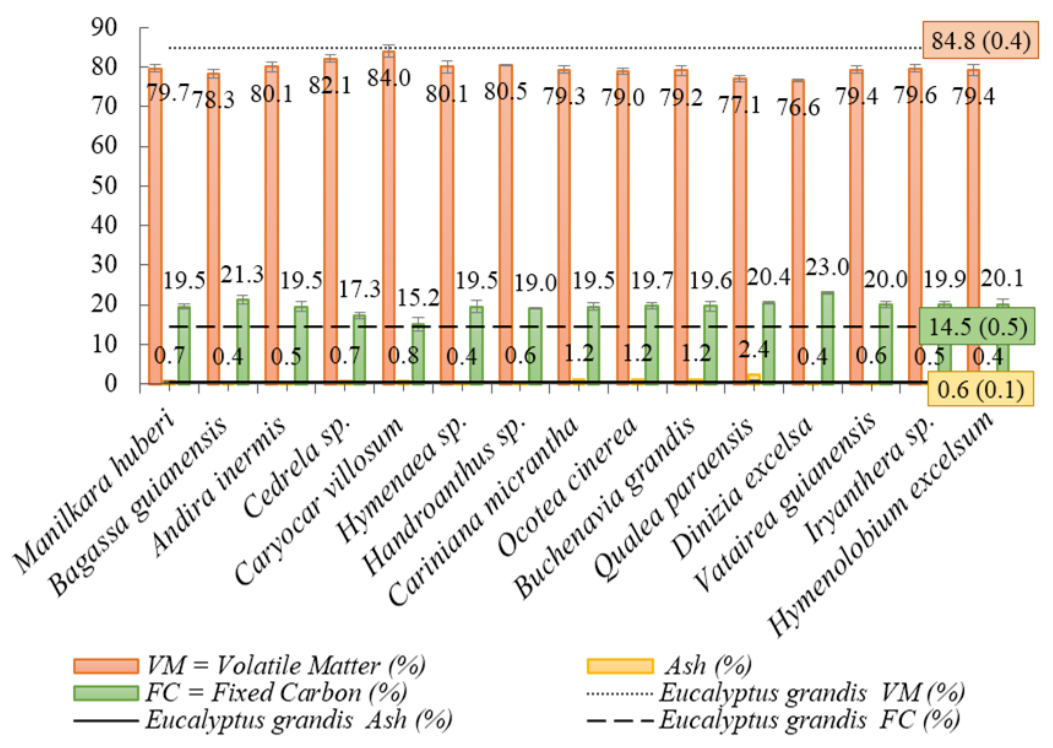

Figure 3. Average values obtained for volatile matter, ash and fixed carbon of residues produced by sawmills in the Amazon Area and Eucalyptus grandis. 
For energy use, according to Lins et al. (2020), species that have high values of volatile matter are easier to ignite. With this information, species with high values of volatile matter could, for example, be used to start burning biomass in a combustion chamber.

Of the fifteen species studied, ten were below $0.8 \%$ for ash (Figure 3), as well as Eucalyptus grandis, a species commonly used for energy plantations (Couto et al., 2013). In this study, ash ranged from 0.4\% (Bagassa guianensis, Hymenaea sp., Dinizia excelsa and Hymenolobium excelsum) to $2.4 \%$ (Qualea paraensis). In the literature, ash values between $0.1 \%$ and $2.0 \%$ were found, respectively, for Bixa arborea (Moutinho et al., 2016) and Dalbergia sp. (Dias et al., 2019); and these are both Amazonian species.

Ash represents the inorganic material present in the wood, and this value represents the amount of material produced at the end of combustion. Ashes are materials that delay the formation of flames, and their accumulation results in incrustations and thickening of the broiler internal wall. This negatively influences the energy conversion rate, making maintenance essential for the removal of this material and, consequently, increasing the production cost (Chen et al., 2016). It is noted that the main species deployed in Rorainópolis, $83 \%$ of the total produced (Crivelli et al., 2017), had an ash content below $0.8 \%$.

When considering the latent need for energy production in the interior regions of the Amazon and the available volume of wood waste produced and stored in the piles, the low ash values measured in most species contributes to the reduction of the amount spent for energy production. This may be explained by the lower need to interrupt the combustion process to remove ash from the boilers. Brand (2010) adds that ash is considered abrasive and with continuous use can cause corrosion of metallic equipment.

In Figure 3, it can be seen that the highest values of fixed carbon (FC) content were obtained from Dinizia excelsa (23.0\%) and Bagassa guianensis (21.3\%). It is noted that Eucalyptus grandis presented the lowest value observed for FC, which was indistinguishable from Caryocar villosum. The observed FC values were between 15.2\% (Caryocar villosum) and 23.0\% (Dinizia excelsa) for the Amazonian species. In the literature, the observed range was $9.1 \%$ to $21.6 \%$ of fixed carbon content, respectively, for Copaifera sp. and Brosimum rubescens (Trugilho et al., 1991), which are both Amazonian species. Note that the range obtained in the literature represents all the species analyzed with the exception of Dinizia excelsa. The explanation for the discrepancy which occurred in Dinizia excelsa may be attributed to the variation of the fixed carbon, based on the age of the individual.

High values of fixed carbon are desirable for biomasses for energy use. The high fixed carbon contributes to the slower burning of biomass. This reduces the constant refueling and helps preventing the formation of flames, which can be a problem depending on the use (Santos et al., 2019).

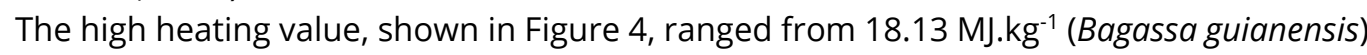
to $20.74 \mathrm{MJ.kg}^{-1}$ (Handroanthus sp.). The high heating value (HHV) of Amazonian species in the

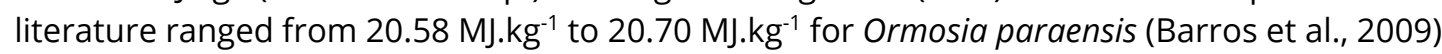
and Ocotea sp. (Silva et al., 2014), respectively. In the study by Quirino et al. (2004), the Brazilian species Buchenavia and Parapiptadenia presented HHV values between $16.09 \mathrm{MJ} . \mathrm{kg}^{-1}$ and $22.36 \mathrm{MJ} . \mathrm{kg}^{-1}$, respectively. The values found in the literature are in the range obtained for all analyzed Amazonian species.

Increased high heating values are desirable for energy production, since this represents the maximum amount of heat released in combustion of a wood mass. However, it is noteworthy that, in addition to the HHV, the species must have a favorable potential for biomass production. Of the fifteen Amazonian species, only Handroanthus sp. and Manilkara

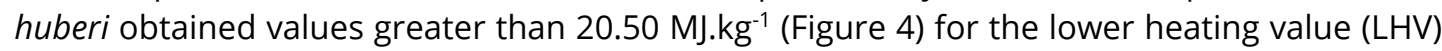
and $5000 \mathrm{MJ} \mathrm{m}^{-3}$ (Figure 5) for the net energy density. These results can be explained by the negative effect of moisture on the LHV, since part of the energy produced is demanded in the drying of the material. Agreeing with previous studies; the species Handroanthus sp. and Manilkara huberi presented the lowest moisture contents in the study (Table 3). 

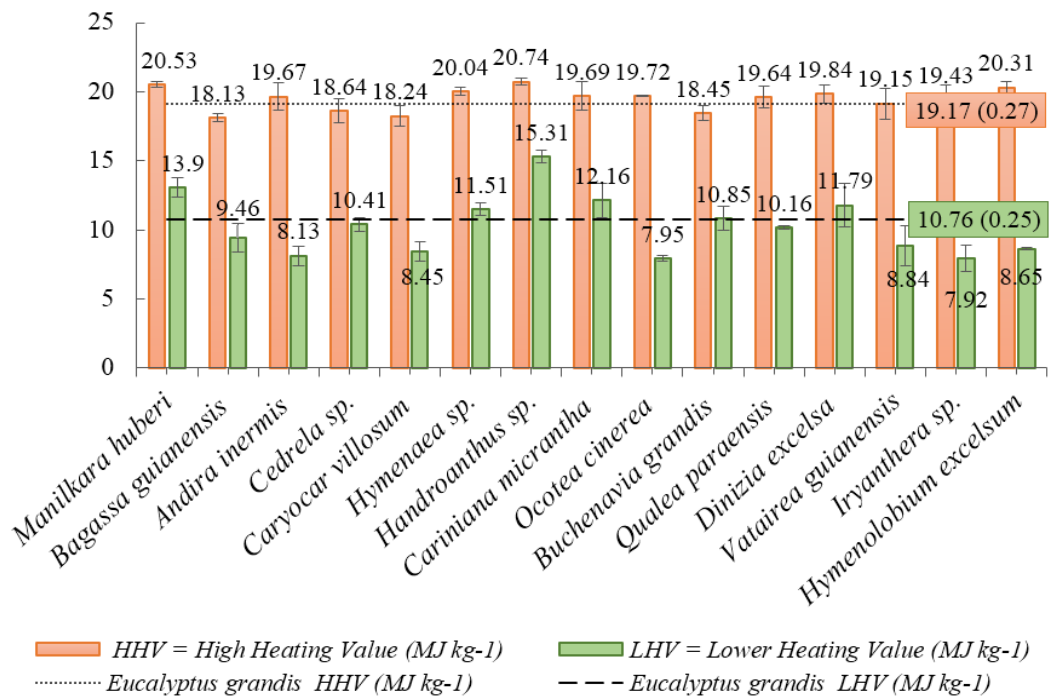

Figure 4. Average values obtained for high and lower heating value of residues produced by sawmills in the Amazon Area and Eucalyptus grandis.

Based on the lower heating values obtained for the material net energy density (Figure 5), it is essential to adopt methods that aim to reduce the residue moisture content. The purpose is to maximize the energetic potential of these species, mainly for the rainy season in the Amazon. It is suggested that studies be carried out to evaluate residue solar drying under a cover (rainy season in the region) or longer storage time in the dry season.

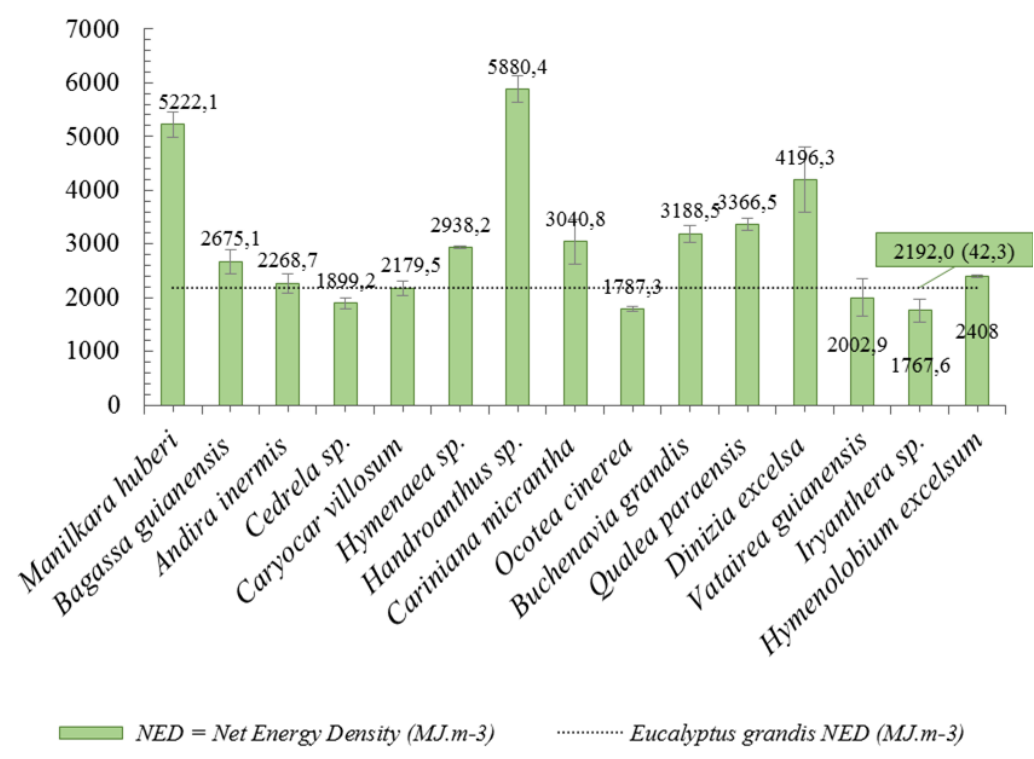

Figure 5. Average values obtained for net energy density of residues produced by sawmills in the Amazon Area and Eucalyptus grandis.

Diesel plants are commonly used in the interior of the Amazon region to generate energy for industries and homes; however, the biomass can be promising, whether in natura or mechanically transformed (pellet or briquette), considering the characteristics analyzed. Damasceno et al. (2017) reported that the cost of kilowatt-hours (kWh) generated by biomass plant is lower than that of the diesel plant. For each $1 \mathrm{kWh}$ produced with the use of biomass, $1.02 \mathrm{~kg}$ of carbon equivalent is emitted to the atmosphere, and this value is lower than those of diesel thermo-electric plants; this should be considered in carbon emissions of the biomass 
life cycle. The same authors reported that biomass plants must prevent the retention of and reduce particulate material and control dioxin and furan emissions.

\section{CONCLUSIONS}

The evaluated species presented different characteristics for the physical, chemical, and energetic tests of wood residues. In general, the Amazonian species showed superior characteristics in comparison to Eucalyptus grandis for energy production. Qualea paraenses, Cedrela sp., Dinizia excelsa, Ocotea cinerea and Buchenavia grandis species are less valuable for energy production, due to the low pH (below 5.0) that might make boiler tubes more vulnerable to corrosion. Based on the data obtained, it would be recommended to adopt pretreatments to dry the residues, as a way to increase the energy performance of biomass and adding value to waste in the Amazon Area.

It is recommended that studies be carried out to assess the chemical and physical effects of storage in different positions in the pile and the behavior of FRLBS subjected to carbonization.

\section{REFERENCES}

American Society for Metals - ASM. (1990). ASM International: corrosion (Vol. 13, 3455 p.). Colorado: ASM.

Araújo, H. J. B. (2007). Relações funcionais entre propriedades físicas e mecânicas de madeiras tropicais brasileiras. Floresta, 37(3), 399-416. http://dx.doi.org/10.5380/rf.v37i3.9937.

Associação Brasileira de Normas Técnicas - ABNT. (1981). NBR 6.922: determinação da massa específica (densidade à granel) (2 p.). Rio de Janeiro: ABNT.

Associação Brasileira de Normas Técnicas - ABNT. (1984a). NBR 8.112: carvão vegetal: análise Imediata (5 p.). Rio de Janeiro: ABNT.

Associação Brasileira de Normas Técnicas - ABNT. (1984b). NBR 8.633: carvão vegetal: determinação do poder calorífico (22 p.). Rio de Janeiro: ABNT.

Associação Brasileira de Normas Técnicas - ABNT. (1987). NBR 7.217: agregados: determinação da composição granulométrica (3 p.). Rio de Janeiro: ABNT.

Associação Brasileira de Normas Técnicas - ABNT. (1997). NBR 7.190: projeto de estruturas de madeira (107 p.). Rio de Janeiro: ABNT.

Associação Brasileira de Normas Técnicas - ABNT. (2003). NBR 11.941: madeira: determinação da densidade básica (6 p.). Rio de Janeiro: ABNT.

Barros, S. V. S., Nascimento, C. C., Azevedo, C. P., Pio, N. S., \& Costa, S. S. (2009). Energetic potential evaluation of the forest species Acacia auriculiformis and Ormosia paraensis cultivated at Iranduba/Amazonas, Brazil. Madera y Bosques, 15(2), 59-69. http://dx.doi.org/10.21829/myb.2009.1521191.

Boa Vista. Fundação Estadual do Meio Ambiente e Recursos Hídricos - FEMARH. (2016, February 2). Instrução normativa n. 002/2016. Diário Oficial do Estado de Roraima. Retrieved in 2021, January 18, from https://www.legisweb.com.br/legislacao/?id=316243

Bowyer, L., Shmulsky, R., \& Haygreen, J. G. (2003). Forest products and wood science: an introduction (554 p.). Ames: Blackwell.

Brand, M. A. (2010). Energia de Biomassa Florestal (114 p.). Rio de Janeiro: Interciência.

Brasil. (2010, August 3). Lei n 12.305, de 2 de agosto de 2010. Política Nacional de Resíduos Sólidos. Diário Oficial [da] República Federativa do Brasil, Brasília. Retrieved in 2021, January 14, from www.planalto.gov.br/ccivil_03/ato2007-2010/2010/lei/12305.htm

Cassilha, A. C., Podlasek, C., Casagrande Junior, E. F., Silva, M. C., \& Mengatto, S. N. F. (2004). Indústria moveleira e resíduos sólidos: considerações para o equilíbrio ambiental. Revista Educação \& Tecnologia, 8(1), 209-228.

Castro, J. P., Perígolo, D. M., Bianchi, M. L., Mori, F. A., Fonseca, A. S., Alves, I. C. N., \& Vasconcellos, F. J. (2015). Use of amazonian species for aging distilled beverages: physical and chemical wood analysis. Cerne, 21(2), 319-327. http://dx.doi.org/10.1590/01047760201521021567.

Chen, K., Hu, T.-H., Perng, Y.-S., \& Chen, C.-S. (2016). Effect of carbon ash content on the thermal and combustion properties of waste wood particle/recycled polypropylene composites. MATEC Web Conferences, 67, 06069. http://dx.doi.org/10.1051/matecconf/20166706069. 
Coelho, M. C. N., Miranda, E., Wanderley, L. J., \& Garcia, T. C. (2010). The energy question in Amazonia: a debate on a new standard of economic and social development. Revista Novos Cadernos NAEA, 13(2), 83-102. http://dx.doi.org/10.5801/ncn.v13i2.475.

Cotton, I. J. (2000). Refinery boiler feedwater systems: corrosion and control. Materials Performance, 39, 46-51.

Couto, A. M., Trugilho, P. F., Neves, T. A., Protásio, T. P., \& Sá, V. A. (2013). Modeling of basic density of wood from Eucalyptus grandis and Eucalyptus urophylla using nondestructive methods. Cerne, 19(1), 27-34. http://dx.doi.org/10.1590/S0104-77602013000100004.

Crivelli, B. R. S., Gomes, J. P., Morais, W. W. C., Condé, T. M., Santos, R. L., \& Bonfim Filho, O. S. (2017). Characterization of the timber sector of Rorainópolis, south of Roraima. Revista Ciência da Madeira, 8(3), 142-150. http://dx.doi.org/10.12953/2177-6830/rcm.v8n3p142-150.

Cruz, B. C. C., Silva, D. A., Oliveira, Á. S., \& Santos, A. B. (2016). Briquette production agricultural waste and sawmill plus "breu yellow" resin. Revista Brasileira de Energias Renováveis, 5(2), 238-252. http://dx.doi.org/10.5380/rber.v5i2.44269.

Damasceno, F. G., Matlaba, V. J., Santos, J. F., \& Mota, J. A. (2017). Reuse of wood ties from Carajás railway for the cogeneration of electricity. Revista Brasileira de Ciências Ambientais, 45, 1-18. http://dx.doi.org/10.5327/Z2176-947820170209.

Dias, J. B., Carvalho, C. E. G., Amorim, P. G. R., Souza, E. M., Kunrath, N. F., \& Marques, D. D. (2019). Evaluation of briquettes produced from Brazil nut (Bertholletia excelsa) bark waste mixture and rosewood (Dalbergia sp.) Sawdust for energy purposes. Brazilian Journal of Development, 5(10), 19841-19869. http://dx.doi.org/10.34117/bjdv5n10-192.

Dorez, G., Ferry, L., Sonnier, R., Taguet, A., \& Lopez-Cuesta, J.-M. (2014). Effect of cellulose, hemicellulose and lignin contents on pyrolysis and combustion of natural fibers. Journal of Analytical and Applied Pyrolysis, 107, 323-331. http://dx.doi.org/10.1016/j.jaap.2014.03.017.

Dzurenda, L., \& Banski, A. (2017). Influence of moisture content of combusted wood on the thermal efficiency of a boiler. Archives of Thermodynamics, 38(1), 63-74. http://dx.doi.org/10.1515/aoter-2017-0004.

Ferreira, I. T. M., Schirmer, W. N., Machado, G. O., \& Gueri, M. V. D. (2014). Estimativa do potencial energético de resíduos celulósicos de fabricação de papel através de análise imediata. Revista Brasileira de Energias Renováveis, 3(4), 284-297. http://dx.doi.org/10.5380/rber.v3i4.38618.

Haberle, I., Haugen, N. E. L., \& Skreiberg, Ø. (2018). Combustion of thermally thick wood particles: a study on the influence of wood particle size on the combustion behavior. Energy \& Fuels, 32(6), 6847-6862. http://dx.doi.org/10.1021/acs.energyfuels.8b00777.

Instituto Brasileiro do Meio Ambiente e dos Recursos Naturais Renováveis - IBAMA. (2021). Relatórios DOF. Retrieved in 2021, June 12, from http://ibama.gov.br/flora-e-madeira/dof/relatorios-dof

Instituto de Pesquisas Tecnológicas - IPT. (2017a). Informações sobre madeiras: Angelim-vermelho. Retrieved in 2021, January 24, from http://www.ipt.br/informacoes_madeiras/23.htm

Instituto de Pesquisas Tecnológicas - IPT. (2017b). Informações sobre madeiras: Maçaranduba. Retrieved in 2021, January 24, from http://www.ipt.br/infor macoes_madeiras/4.htm

Instituto de Pesquisas Tecnológicas - IPT. (2017c). Informações sobre madeiras: Ipê. Retrieved in 2021, January 24, from http://www.ipt.br/informacoes_madeiras/38.htm

Instituto de Pesquisas Tecnológicas - IPT. (2017d). Informações sobre madeiras: Angelim-amargoso. Retrieved in 2021, January 24, from http://www.ipt.br/informacoes_madeiras/51.htm

Iwakiri, S., Trianoski, R., Nascimento, C. C., Gumane, C., Lengowski, E. C., Schardosin, F. Z., \& Azambuja, R. (2015). Strength of glued joints of Inga alba (sw) willd and Swartzia recurva poepp wood. Cerne, 21(3), 457-463. http://dx.doi.org/10.1590/01047760201521031844.

Klock, U., Muniz, G. I. B., Andrade, A. S., \& Anzaldo, J. H. (2006). Química da madeira (3. ed., Série Didática, 114 p.). Curitiba: FUPEF.

Lins, T. R. S., Braz, R. L., Souza Junior, C. G. C., Correia, H. T. V., Silva, T. C., \& Walter, L. S. (2020). Yield and characterization of charcoal from Mimosa caesalpiniifolia Benth. BIOFIX Scientific Journal, 5, 39-43. http://dx.doi.org/10.5380/biofix.v5i1.67394.

Melo, R. R., Dacroce, J. M. F., Rodolfo Junior, F., Lisboa, G. S., \& França, L. C. J. (2019). Lumber yield of four native forest species of the Amazon region. Floresta e Ambiente, 26(1), e20160311. http://dx.doi.org/10.1590/2179-8087.031116.

Moutinho, V. H. P., Rocha, J. J. M., Amaral, E. P., Santana, L. G. M., \& Águiar, O. J. R. (2016). Chemical and energetic properties of amazonian woods of the second cutting cycle. Floresta e Ambiente, 23(3), 443-449. http://dx.doi.org/10.1590/2179-8087.131715. 
Namduri, H., \& Nasrazadani, S. (2008). Quantitative analysis of iron oxides using Fourier transform infrared spectrophotometry. Corrosion Science, 50(9), 2493-2497. http://dx.doi.org/10.1016/j.corsci.2008.06.034.

Nascimento, C. C., Garcia, J. N., \& Diáz, M. P. (2016). Agrupamento de espécies madeireiras da Amazônia em função da densidade básica e propriedades mecânicas. Madera y Bosques, 3(1), 33-52. http://dx.doi.org/10.21829/myb.1997.311378.

Obernberger, I., \& Thek, G. (2004). Physical characterisation and chemical composition of densified biomass fuels with regard to theircombustion behaviour. Biomass and Bioenergy, 27(6), 653-669. http://dx.doi.org/10.1016/j.biombioe.2003.07.006.

Paixão, C. P. S., Vieira, G. C., Barberena, I. M., Melo, L. C., \& Freitas, L. C. (2014). Production and disposal of waste generated in sawmills in the municipality of Rolim de Moura - RO. Revista Brasileira de Ciências da Amazônia, 3, 47-56. http://dx.doi.org/10.4322/floram.2012.051.

Pereira, J. C. D., Sturion, J. A., Higa, A. R., Higa, R. C. V., \& Shimizu, J. Y. (2000). Características da madeira de algumas espécies de eucalipto plantadas no Brasil (Documentos, No. 38, 113 p.). Colombo: Embrapa Florestas.

Pinheiro, G. F., Rendeiro, G., \& Pinho, J. T. (2005). Energy density of plant residues. Biomassa \& Energia, 2(2), 113-123.

Quirino, W. F., Vale, A. T., Andrade, A. P. A., Abreu, V. L. S., \& Azevedo, A. C. S. (2004). Poder calorífico da madeira e de resíduos lignocelulósicos. Biomassa \& Energia, 1(2), 173-182.

Ramos, W. F., Ruivo, M. L. P., Jardim, M. A. G., \& Sousa, L. M. (2018). Generation of wood waste from the forest based sector in the metropolitan region of Belém, Pará state. Ciência Florestal, 28(4), $1823-$ 1830. http://dx.doi.org/10.5902/1980509835341.

Santana, M. A. E., \& Okino, E. Y. A. (2007). Chemical composition of 36 Brazilian Amazon forest wood species. Holzforschung, 61(5), 469-477. http://dx.doi.org/10.1515/HF.2007.084.

Santos, F., Colodette, J., \& Queiroz, J. H. (2013). Bioenergia e biorrefinaria: cana-de-açúcar e espécies florestais (551 p.). Viçosa: Editora UFV.

Santos, R. C., Carneiro, A. C. O., Damasceno, G. R. F., Castro, A. F. N. M., Castro, R. V. O., Costa, L. S., \& Costa, S. E. L. (2019). Efeito da variabilidade de resíduos madeireiros na produção e qualidade de briquetes. Advances in Forestry Science, 6(1), 529-534. http://dx.doi.org/10.34062/afs.v6i1.7145.

Sarto, C., \& Sansigolo, C. A. (2010). Kinetics of the removal of Eucalyptus grandis wood extractives during Kraft pulping. Acta Scientiarum. Technology, 32(3), 227-235. http://dx.doi.org/10.4025/actascitechnol.v32i3.4237.

Silva, D. A., Almeida, V. C., Viana, L. C., Klock, U., \& Muñiz, G. I. B. (2014). Evaluation of the energy-related properties of tropical wood waste using NIR spectroscopy. Floresta e Ambiente, 21(4), 561-568. http://dx.doi.org/10.1590/2179-8087.043414.

Soares, C. R. A., Sá, H. R. A., Rodrigues, M., \& Goulart, S. L. (2018). Management and competitiveness: furniture cluster analysis in the Amazon. Revista de Estudios Sociales, 20(41), 144-159. http://dx.doi.org/10.19093/res7114.

Technical Association of the Pulp and Paper Industry - TAPPI. (2006). Standard T222 os -74 (14 p.). Atlanta: TAPPI.

Technical Association of the Pulp and Paper Industry - TAPPI. (2007). Standard T 204 cm-97 (12 p.). Atlanta: TAPPI.

Tom \& Peter Flooring Inc. (2021). Hardwood floors durability. Retrieved in 2021, January 20, from http://tompeterflooring.com/flooring/hardwood-floors-durability

Trugilho, P. F., Silva, D. A., Frazão, F. J. L., \& Regazzi, A. J. (1991). Characterization of native and exotic species of the amazon and of the wood charcoal. Revista Árvore, 15(2), 144-151.

Valério, A. F., Watzlawick, L. F., Silvestre, R., \& Koehler, H. S. (2009). Determination of the basic density of cedro wood (Cedrela fissilis Vell.) along the stem. Applied Research \& Agrotechnology, 1, 23-28. http://dx.doi.org/10.5777/paet.v1i1.5.

Zau, M. D. L., Vasconcelos, R. P., Giacon, V. M., \& Lahr, F. A. R. (2014). Chemical, physical and mechanical properties of particleboard produced with Amazon wood waste - Cumaru (Dipteryx Odorata) - and castor oil based polyurethane adhesive. Polímeros, 24(6), 726-732. http://dx.doi.org/10.1590/0104-1428.1594.

Authors' contributions: WW: Conceptualization, Data curation, Formal Analysis, Investigation, Methodology, Project administration, Validation, Visualization, Writing - original draft, Writing - review \& editin; JO: Conceptualization, Formal Analysis, Investigation, Methodology, Project administration; Supervision, Validation; AQ: Conceptualization, Investigation, Methodology; AF: Conceptualization, Investigation, Methodology; JB: Investigation, Methodology, Visualization. 